Sławomir Kapralski

ORCID: 0000-0002-4215-7693

Uniwersytet Pedagogiczny w Krakowie

\title{
Niedyskursywna pamięć traumatyczna a tożsamość zbiorowa. Romowie wobec doświadczenia zagłady
}

Abstrakt: Przedmiotem artykułu jest romska pamięć niedyskursywna, czyli niewyrażana w mowie czy w piśmie obecność przeszłości w praktykach, relacjach, strukturach społecznych i hierarchiach kulturowych. Ta forma pamięci odgrywa szczególnie istotną rolę w wypadku Romów, a więc sieci zbiorowości, które w przeszłości miały utrudniony dostęp do środków wytwarzania pamięci zbiorowej. Autor nawiązuje do teorii systemów i antropologii symbolicznej Mary Douglas, by pokazać, w jaki sposób lęki spowodowane przez traumatyczne wydarzenia historyczne, związane z naruszeniem zewnętrznej granicy społeczności romskiej, są w niedyskursywny sposób kodowane w jej strukturze społecznej i kulturze. W konsekwencji autor stawia tezę, że niemożność kontroli granicy zewnętrznej (na przykład skutecznej obrony przed prześladowaniami) prowadzi do kompensacyjnej kontroli granic wewnątrzgrupowych (na przykład wzmocnienia patriarchalnej relacji między kobietami a mężczyznami). Tezę tę potwierdza odmienny status kobiet w skądinąd kulturowo podobnych grupach polskich Romów Karpackich i Romów słowackich, który badacz wyjaśnia odmiennymi dla obu grup doświadczeniami II wojny światowej i związanymi z tym różnymi formami pamięci niedyskursywnej.

Słowa-klucze: niedyskursywna pamięć zbiorowa, tożsamość zbiorowa, Romowie, genealogie pamięci, wydarzenie traumatyzujące, kodowanie lęku, patriarchalne relacje między płciami

\section{Wprowadzenie}

W niniejszym artykule interesuje mnie pamięć niedyskursywna, a więc taka, która - idąc za Mirosławą Marody — ,powinna być rekonstruowana raczej przez analizę konkretnych zachowań aktorów zaangażowanych w konkretne interakcje

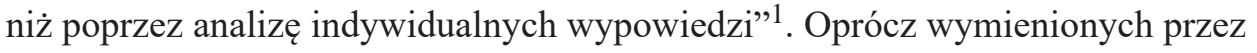
autorkę zachowań poszukiwania pamięci zbiorowej należy prowadzić również

${ }^{1}$ M. Marody, Jednostka po nowoczesności. Perspektywa socjologiczna, Warszawa 2014, s. 232233. 
w sferze struktury społecznej oraz w pewnych wyborach czy preferencjach kulturowych. Jest to zatem pamięć specyficzna: niewyrażana w mowie czy piśmie, a jednak poprzez obecność w rozmaitych praktykach, relacjach społecznych, obyczajach i nastawieniach aksjologicznych ciągle przypominająca, że powinniśmy pamiętać o tym, że mamy zapomnieć albo że powinniśmy zapomnieć o tym, że ciągle mimo wszystko pamiętamy. W literaturze polskiej podobne zjawiska bada Roma Sendyka, określając je zbiorczo jako „niepamięć” lub „pamięć wernakularną”, w której „,milcząca wiedza łączy się z »zaniechaniem mowy«, gdzie przeszłość jest zniekształcana do dającego się znieść na poły fantastycznego mitu; gdzie odsłania się tylko minimalnie, dzięki gestom, deformacjom wypowiedzi, użyciu obiektów"2. W odróżnieniu jednak od tej koncepcji mnie interesują jedynie takie obszary życia społecznego i kultury, które nie są w jakikolwiek sposób związane z pamięcią, a które jednak w jakiś sposób kodują przeszłość grupy, a kodowanie to ma duże znaczenie dla jej tożsamości.

Tak rozumianą pamięć niedyskursywną staram się następnie umieścić w teoretycznych ramach badań nad pamięcią, a mianowicie w kontekście dwóch genealogii pamięci: oddolnej — prowadzącej od indywidualnych wspomnień, przez ich komunikowanie innym, do kulturowych instytucji podtrzymujących oficjalną pamięć zbiorową grupy - i odgórnej, gdzie wizje przeszłości są wytwarzane na poziomie instytucjonalnym, który organizuje społeczną komunikację na temat przeszłości, a nawet indywidualne wspomnienia.

W pamięci zbiorowej różnych grup romskich znajdujemy wiele elementów pamięci niedyskursywnej, co wiąże się ze słabością zarówno oddolnej, jak i odgórnej genealogii pamięci, wynikającą zarówno z traumatycznych doświadczeń historycznych, jak i społecznej marginalizacji w teraźniejszości. Romowie to społeczność licząca około 12 milionów osób, składająca się z sieci pokrewnych kulturowo grup o wspólnym pochodzeniu etnicznym, jednakże bardzo się od siebie różniących - w tym odmiennymi losami historycznymi, a tym samym różnymi zasobami mnemonicznymi. W dalszej części artykułu staram się pokazać problemy, jakie sprawia Romom tworzenie szerzej podzielanych form pamięci, upatrując genezy tych problemów w ludobójczych prześladowaniach, jakich wiele grup romskich doznało w czasie II wojny światowej.

Główna część argumentacji poświęcona jest stworzeniu modelu romskiej tożsamości, który unikałby problemów kulturowego esencjalizmu i socjologicznego ahistoryzmu, dominujących w badaniach nad Romami. Model ten, inspirowany teorią systemów i antropologią Mary Douglas, traktuje pewne elementy romskiej kultury i życia społecznego (na przykład dychotomię „czyste-nieczyste” czy „męskie-żeńskie”) jako sposób niedyskursywnego kodowania traumatycznej przeszłości. Jego zalety przedstawię w nawiązaniu do empirycznych badań po-

2 R. Sendyka, Niepamięć albo o sytuowaniu wiedzy o formach pamiętania, „Teksty Drugie” 2015, nr 6, s. 264. 
glądów działaczek romskich organizacji pozarządowych, należących do trzech różnych grup romskich.

\section{Teoretyczny układ odniesienia}

Zdroworozsądkowe podejście do pamięci ukazuje ją jako odciśnięcie się przeszłości w teraźniejszości za pomocą wspomnienia. Pamięć jest tu rozumiana jako mneme - mniej lub bardziej ciągły przekaz przeszłych doświadczeń. Podejście alternatywne ukazuje pamięć jako anamnesis ${ }^{3}$, który to proces rozumiem nie jako przypominanie sobie czegoś, co zostało zapomniane, lecz jako konstruowanie przeszłości w określony sposób znaczącej w procesie budowania lub obrony tożsamości, dokonującym się $\mathrm{w}$ teraźniejszości z odniesieniem do przyszłości. $\mathrm{W}$ procesie tym wytwarzane są wizje przeszłości, zapośredniczone przez przestrzeń, w której żyjemy, i sieci komunikacyjne, w których uczestniczymy ${ }^{4}$.

Takie alternatywne podejście podkreśla, jak pisze Jonathan Friedman, że

przeszłość jest zawsze sprawą teraźniejszości, nie dlatego, że się teraźniejszości narzuca, lecz dlatego, że żyjące w teraźniejszości podmioty kształtują przeszłość w toku praktykowania ich społecznych tożsamości. [...] Przeszłość, która oddziałuje na teraźniejszość, jest przeszłością tworzoną i/lub odtwarzaną w teraźniejszości ${ }^{5}$.

Pamięć rozumiana jako mneme jest bardziej wyraźna, gdy wspominane wydarzenia nie są zbyt odległe. Wraz z upływem czasu, gdy umierają uczestnicy przeszłych wydarzeń, pamięć taka nieuchronnie blaknie i ulega zniekształceniom w trakcie przekazu międzypokoleniowego. Z kolei pamięć jako anamnesis jest tym bardziej dokładna, im więcej czasu upłynęło od wydarzeń będących jej przedmiotem. Gdy wiemy, jak pamiętać jakieś wydarzenie, pamiętamy je lepiej, taka zaś wiedza pojawia się dopiero wraz z upływem czasu.

Uważa się czasami, że pamięć typu mneme jest pamięcią autentyczną, podczas gdy pamięć typu anamnesis jest często rezultatem instrumentalnej manipulacji. Nie musi tak jednak być. Jak wiadomo, naoczni świadkowie mogą nie zdawać sobie sprawy z tego, co naprawdę widzieli, natomiast dystans czasowy może sprzyjać lepszemu rozumieniu przeszłości. Oba rodzaje pamięci mają po prostu inne zalety i wady. Mneme komunikuje szczegółowe i bezpośrednie doświadczenie, dostępne tylko tym, którzy osobiście doświadczyli przeszłości, lecz często nie może nam pomóc w jej zrozumieniu. Anamnesis zaś nie jest tak szczegółowa, lecz potrafi nadawać przeszłości znaczenie i integrować ją z teraźniejszością.

3 Y.H. Yerushalmi, Zakhor: Jewish History and Jewish Memory, Seattle 1996, s. 107.

${ }^{4}$ G. Delanty, Social Theory in a Changing World. Conceptions of Modernity, Cambridge 1999, s. 71 .

5 J. Friedman, Cultural Identity and Global Process, London 1994, s. 141; jeśli nie podano inaczej, przeł. S.K. 
Na przykład gdy Michael C. Steinlauf pisze, że nieżydowscy Polacy, będący według niego pasywnymi świadkami Holokaustu, widzi eli, co się stało z Żydami, lecz nie wie dzi eli, co ich spotkało ${ }^{6}$, oznacza to w zastosowanej przeze mnie terminologii, że zapamiętali oni los Żydów w trybie mneme, lecz nie byli zdolni do włączenia trybu anamnesis, aby w pełni zrozumieć, czego właściwie byli świadkami. Mogło to być spowodowane wieloma przyczynami. Po pierwsze, w czasie swego trwania i w ciągu pierwszej dekady po zakończeniu II wojny światowej zagłada europejskich Żydów nie była uznawana za coś znacząco odmiennego od innych zbrodni wojennych ${ }^{7}$. Po drugie, przez dość długi czas nie miała też swej odrębnej nazwy własnej, co ważne, gdyż — jak zauważa Jeffrey Alexander — nawet obiektywnie bardzo istotne wydarzenia historyczne mogą być dla ich uczestników „niewidzialne”, jeśli nie istnieje narracja, która je nazywa i nadaje im znaczenie $^{8}$. Po trzecie, jak również zauważył Alexander ${ }^{9}$, los ofiar może pozostać niezauważony, gdy świadkowie się z nimi nie identyfikują i w związku z tym nie tworzą wspólnoty mnemonicznej ${ }^{10}$. Po czwarte, świadkowie zagłady bardzo często nie mają czystego sumienia, pasywnie bądź aktywnie w niej uczestnicząc lub czerpiąc z niej korzyści, co później zostaje wyparte i wymazane z pamięci wraz z całym kontekstem historycznym wypartych doświadczeń, a następnie zastąpione rozmaitymi ideologicznymi fantazmatami ${ }^{11}$.

W przeciwieństwie do tego pamięć Zagłady rozwijana w ostatnich dekadach, zwłaszcza w swojej zglobalizowanej ${ }^{12}$ czy kosmopolitycznej ${ }^{13}$ formie, oferuje szeroki zakres interpretacji $\mathrm{w}$ trybie anamnesis, które jednakże stopniowo tracą związek z interpretowanym wydarzeniem i - jak krytycznie zauważa Eva Hoffman - są zagrożone przez inflację pustej retoryki ${ }^{14}$. Mogą także być po prostu odrzucane przez całe grupy, gdyż zagrażają ich bezpieczeństwu mnemoniczne$\mathrm{mu}^{15}$.

6 M.C. Steinlauf, Bondage to the Dead. Poland and the Memory of the Holocaust, Syracuse 1997, s. 53.

7 D. Levy, N. Sznaider, The Holocaust and Memory in the Global Age, Philadelphia 2006, s. 16.

8 J.C. Alexander, Trauma. A Social Theory, Cambridge 2012, s. 19.

9 Ibidem.

${ }^{10} \mathrm{Na}$ temat pojęcia wspólnoty mnemonicznej zob. E. Zerubavel, Hidden in Plain Sight: The Social Structure of Irrelevance, Oxford 2015, s. 10.

11 A. Leder, Prześniona rewolucja. Ćwiczenie z logiki historycznej, Warszawa 2014.

12 A. Huyssen, Present pasts: Media, politics, amnesia, „Public Culture” 12, 2000, nr 1.

13 D. Levy, N. Sznaider, Memory unbound: The Holocaust and the formation of cosmopolitan memory, „European Journal of Social Theory” 5, 2002, nr 1.

14 E. Hoffman, After Such Knowledge. A Meditation on the Aftermath of the Holocaust, London 2004.

15 Zob. M. Mälksoo, ,, Memory must be defended”: Beyond the politics of mnemonical security, „Security Dialogue” 46, 2015, nr 3; S. Kapralski, The Holocaust: Commemorated but not remembered? Post-colonial and post-traumatic perspectives on the reception of the Holocaust memory discourse in Poland, „Journal of Historical Sociology” 31, 2018, nr 1. 
Jednakże wyróżnione koncepcje czy też tryby pamięci nie muszą być rozłączne. Można wyobrazić sobie schemat teoretyczny, w którym mogą one wspólistnieć jako dwie zasady organizujące relacje między różnymi poziomami pamięci: pamięcią indywidualną, społeczną pamięcią komunikacyjną i zbiorową pamięcią kulturową. Pamięć indywidualną tworzą wspomnienia przeszłości charakteryzujące daną jednostkę. Gdy różne jednostki komunikują i dyskutują swoje wspomnienia, część z nich staje się społeczną (komunikacyjną) pamięcią charakteryzującą daną grupę. Wreszcie gdy ramy kulturowe i instytucje społeczne wspierają (a czasami wzbudzają, a nawet tworzą) pewne formy pamięci społecznej (i osłabiają lub eliminują inne), wówczas powstaje kulturowa (zbiorowa) pamięć danej społeczności, która

jest oparta na selekcji i wykluczeniu, dokładnie oddzielając wspomnienia użyteczne od bezużytecznych, ważne od nieważnych. Tym samym pamięć zbiorowa jest z konieczności pamięcią zapośredniczoną przez media. Wspierają ją media materialne, symbole i praktyki, które muszą zostać zaszczepione w sercach jednostek ${ }^{16}$.

Dotyczy to nawet pamięci o wydarzeniach niezwykłej wagi — nie są one zapamiętywane, ponieważ się wydarzyły i były istotne. Pamiętamy o nich, ponieważ skłania nas do tego instytucjonalny aparat kulturowy, określający, co jest warte wspomnienia i w jaki sposób. Dotyczy to nawet Zagłady — jak pisze Oren Baruch Stier, ,pamięć Holokaustu jest czymś ważnym, ponieważ została taką uczyniona przez formy i instytucje kulturowe, które zapośredniczają obecność Holokaustu w teraźniejszości” 17 .

Czerpiąc inspirację z teorii systemu społecznego Talcotta Parsonsa ${ }^{18}$, uważam, że wspomniane trzy poziomy pamięci mogą być względem siebie usytuowane w dwojaki sposób, przez dwie różne sekwencje czy genealogie pamięci, które razem składają się na społeczny proces pamiętania. Pierwszy proces, zmierzający „od dołu do góry”, zorganizowany jest zgodnie z zasadą „dystrybucji energii” i wiedzie od jednostkowych wspomnień, które dostarczają materiału pamięci społecznej, a następnie wskutek działalności instytucji kulturowych i politycznych zostają zakumulowane w różnych formach pamięci zbiorowej. Proces drugi zmierza w odwrotnym kierunku („góra-dół”), zgodnie z zasadą „kontroli informacji”, i prowadzi od instytucjonalnej pamięci zbiorowej, która wzmacnia pewne formy komunikacji właściwe pamięci społecznej, marginalizuje zaś inne, co w rezultacie decyduje o tym, jakie indywidualne wspomnienia będą mogły stać się przedmiotem komunikacji i jaki kształt ona przybierze.

16 A. Assmann, Transformations between history and memory „Social Research” 75, 2008, nr 1, s. 55.

17 O.B. Stier, Committed to Memory. Cultural Mediations of the Holocaust, Amherst-Boston 2003, s. 1 .

18 J. Scott, Conceptualising the Social World. Principles of Sociological Analysis, Cambridge 2011, s. 109-110. 
Według Aleidy Assmann drugi z wymienionych procesów, przekształcający „efemeryczną pamięć społeczną w długotrwałą pamięć zbiorową”, obejmuje:

umieszczenie wydarzeń w emocjonalnie naładowanej i mobilizującej narracji, wizualne i werbalne znaki służące jako wspomaganie pamięci, instytucje edukacyjne i rozpowszechnianie za pomocą mass mediów, miejsca i pomniki stanowiące materialne zabytki przeszłości, zbiorowe uczestnictwo w rytuałach upamiętniających, które okresowo reaktywują pamięć ${ }^{19}$.

Należy jednak zauważyć, że skuteczność tego procesu zależy między innymi od siły indywidualnych wspomnień dostarczających mu energii.

Przedstawiona tu współpraca dwóch genealogii pamięci dopiero od niedawna charakteryzuje społeczności romskie i właściwą im pamięć ich losu w czasie Holokaustu. W przeszłości pamięć typu mneme była fragmentaryczna — poszczególne grupy miały bardzo różne wspomnienia przeszłości. Nawet pamięć jednej grupy mogła być podzielona i niespójna: poszczególne odłamy grupy mogły pamiętać w odmienny sposób, a zapamiętana przeszłość była często zbyt skomplikowana, aby pozostawić jednolity ślad mnemoniczny w świadomości członków. Co więcej, z rozmaitych powodów natury psychologicznej, kulturowej i politycznej indywidualne wspomnienia Romów były często poddane represji, ukryte i odizolowane od innych, a tym samym zbyt słabe, by dostarczyć energii procesowi pamięci.

Z kolei romska anamnesis, konstrukcja pamięci zbiorowej/kulturowej, była przez długi czas hamowana, gdyż Romowie aż do niedawna nie tworzyli i nie kontrolowali istniejących instytucji, miejsc pamięci, pomników, rytuałów i praktyk, w których i poprzez które narracje przeszłości są wytwarzane, rozpowszechniane i powszechnie podzielane. W rezultacie genealogia „od dołu do góry” nie była w stanie dostarczyć procesowi pamięci wystarczającej energii, genealogia zaś „góra-dół” nie znajdowała się w rękach Romów i nie mogła skutecznie organizować rozproszonych i słabnących wspomnień jednostek oraz tego, jak komunikowały się one na temat przeszłości.

\section{Romowie po ludobójstwie}

Z powodu braku danych nie można precyzyjnie określić liczby romskich ofiar prześladowań, jakie spotkały tę społeczność w czasie II wojny światowej. Badacze polegający wyłącznie na istniejących źródłach archiwalnych mówią o 100 250 tysiącach ofiar (zgadzając się przy tym, że ich rzeczywista liczba musi być większa). Ci, którzy dokonują szacunków na podstawie różnych źródeł pośrednich, mówią czasem nawet o 1,5 miliona ofiar. Liczba 500 tysięcy jest powszech-

19 A. Assmann, op. cit., s. 55-56. 
nie akceptowana jako „symboliczna” 20 i jednocześnie realistyczna. Często posługują się nią politycy i działacze romscy w trakcie uroczystości upamiętniających.

Jednakże nawet jeśli znalibyśmy dokładną ogólną liczbę romskich ofiar, wiedza ta nie byłaby w wielu przypadkach użyteczna ze względu na odmienne losy różnych grup romskich. Wiele romskich społeczności zostało niemal całkowicie wymordowanych. W tym samym czasie inne grupy nie były obiektem prześladowań lub dotknęły je one w niewielkim stopniu. Do pierwszej kategorii należą grupy romskie z Niemiec, Austrii, Chorwacji, Czech i Moraw, Holandii, Łotwy, Litwy, Estonii oraz niektórych innych części okupowanego Związku Radzieckiego, które straciły między 50 a 90\% swoich członków. Inne grupy w tych krajach, a także niektóre społeczności polskich, serbskich czy węgierskich Romów straciły między 20 a 30\% członków. Z drugiej strony mamy grupy Romów rumuńskich, włoskich, francuskich czy słowackich, które straciły mniej niż 10\% członków, a nawet, jak w wypadku Romów bułgarskich, niemal w ogóle nie były ofiarami ludobójczych prześladowann ${ }^{21}$.

Oczywiście wszystkie podane tu odsetki są jedynie szacunkowe. Jedyną rzeczą, której możemy być pewni, jest to, że różne grupy Romów ucierpiały w odmienny sposób i w innym stopniu. Niektóre z nich przestały istnieć, innym udało się przeżyć pomimo wielkich strat, jeszcze inne nie doświadczyły prześladowań na większą skalę. To zróżnicowanie wojennych losów przyczyniło się do odmiennych losów różnych grup po wojnie: podczas gdy niektóre z nich walczyły o biologiczne przetrwanie, o odszkodowania i uznanie ich statusu ofiar, inne usiłowały kontynuować przerwane wojną normalne życie.

Zróżnicowanie losów poszczególnych społeczności szło w parze z desynchronizacją: członkowie jednej grupy romskiej mogli mieć w różnych okresach bardzo odmienne doświadczenia. Na przykład niemiecki Sinti mógł zostać pozbawiony praw obywatelskich $\mathrm{w}$ rezultacie ustaw norymberskich, osadzony w obozie koncentracyjnym lub specjalnym „obozie cygańskim” i poddany sterylizacji w związku z ,prawem o zapobieganiu chorobom dziedzicznym”, aby w 1940 roku zostać wcielonym do armii niemieckiej, walczyć na froncie wschodnim, zostać rannym, otrzymać odznaczenie, a następnie w końcu 1942 roku być wysłanym na urlop, aresztowanym $\mathrm{w}$ jego trakcie i deportowanym do KL Auschwitz wraz z rodziną. Jeśli udało mu się przeżyć pierwsze miesiące w Zigeunerlager w Auschwitz, mógł zostać — częściowo dzięki swej służbie wojskowej — przeniesiony do obozu pracy w Niemczech (często zostawiając w Auschwitz rodzinę, która później zostawała zgładzona), a pod koniec wojny przymusowo wcielony do oddziałów

20 D. Kenrick, The genocide of the Gypsies: What we now know and what we still don't know, „The Holocaust in History and Memory” 3, 2010.

21 Zob. ibidem; B.D. Lutz, J.M. Lutz, Gypsies as victims of the Holocaust, „Holocaust and Genocide Studies" 9, 1995, nr 3; D. Kenrick, G. Puxon, Gypsies under the Swastika, Hatfield 1995; D.M. Crowe, Reflections on the Roma and the Holocaust, [w:] Roma and Sinti. Under-Studied Victims of Nazism. Symposium Proceedings, Washington 2004. 
walczących z nacierającą Armią Czerwoną jako ostatnia linia oporu reżimu, który go prześladował.

Ta niespójność romskiego losu była uwarunkowana specyficznym charakterem nazistowskich prześladowań Romów ${ }^{22}$ i prowadziła do fragmentacji pamięci romskich społeczności, co oznaczało nie tylko, że różne społeczności miały odmienne wspomnienia, lecz również, że członkowie jednej społeczności nie byli w stanie przedstawić spójnej narracji swoich losów. Dobrym przykładem jest sytuacja Romów rumuńskich, podzielonych przez sprzymierzone z III Rzeszą władze swego kraju na dwie kategorie. Pamięć potomków członków pierwszej z nich jest pamięcią deportacji i śmierci z głodu czy chorób, podczas gdy niektórzy potomkowie członków drugiej grupy kultywują wspomnienia wspólnej z etnicznymi Rumunami służby wojskowej, walki na froncie i rodzącego się poczucia społecznej akceptacji ${ }^{23}$. Taka fragmentacja była wzmocniona problemami tradycyjnej romskiej kultury z interpretacją i komunikowaniem historii cierpienia i prześladowań, problemami romskich społeczności związanymi ze spowodowanym prześladowaniami rozpadem więzi tworzących romski świat społeczny, a wreszcie psychologicznymi problemami jednostek wynikającymi z doznanej przez nie traumy.

Trauma wywołana doświadczeniem ludobójstwa i powojennego kryzysu tradycyjnej kultury romskiej przejawiała się między innymi w zwątpieniu w mechanizmy regulujące romskie życie i nadające mu znaczenie, a także we frustracji spowodowanej tym, że po zakończeniu wojny Romowie nadal byli dyskryminowani, odmawiano im uznania ich cierpienia i kompensacji ${ }^{24}$. W krajach komunistycznych Romowie byli po wojnie poddani przymusowej asymilacji, co czasem oznaczało radykalną zmianę trybu życia i kolejną sytuację traumatyczną.

Jednakże dla części Romów asymilacja stała się świadomie wybraną strategią adaptacyjną. Wierzyli oni bowiem, że zagwarantuje im bezpieczeństwo. Niestety w większości przypadków próby asymilacyjne kończyły się w liminalnej strefie między tradycyjną kulturą romską a kulturą większości, asymilujący się zaś Romowie tracili wsparcie pierwszej, nie otrzymując go od drugiej. Inna część Romów wybrała izolację od nieromskiego otoczenia (na tyle, na ile było to możliwe) i usiłowała odtworzyć kulturę tradycyjną, co w istocie rzeczy oznaczało tworzenie jej na nowo. Zjawisko to, znane jako retradycjonalizacja, jest kluczowe do zrozumienia niedyskursywnych form romskiej pamięci i zostanie omówione w dalszej części artykułu.

22 Zob. M. Zimmermann, The Wehrmacht and the national socialist persecution of the Gypsies, „Romani Studies” 11, 2001, nr 2, s. 112; M. Stewart, How does genocide happen?, [w:] Questions of Anthropology, red. R. Astuti, J. Parry, C. Stafford, Oxford 2007.

23 Zob. R. Ioanid, The Holocaust in Romania. The Destruction of Jews and Gypsies Under the Antonescu Regime 1940-1944, Chicago 2000.

24 Zob. J. Von dem Knesebeck, The Roma Struggle for Compensation in Post-War Germany, Hatfield 2011. 


\section{Amnezja kulturowa czy wykluczenie mnemoniczne?}

Zasadniczo rzecz ujmując, stan psychiczny ocalałych z ludobójstwa nie sprzyjał kultywowaniu pamięci, a już szczególnie przekształcaniu jej w solidne formy kulturowe i sformalizowane działania upamiętniające. Kryzys kultury związany był bowiem w ich wypadku z kryzysem indywidualnych mechanizmów poznawczych odpowiedzialnych za nadawanie znaczenia przeszłości. Przeszłość była czasem złym, którego przywoływanie powodowało dyskomfort i frustrację. Nie mogły temu zapobiec osłabione formy kulturowe odpowiedzialne za przekazywanie wiedzy o przeszłości. Psychologia uczy, że horyzont temporalny ludzi uczestniczących $\mathrm{w}$ traumatyzujących wydarzeniach i cierpiących z powodu zespołu stresu pourazowego jest często ograniczony do bezpośredniej teraźniejszości: nie przechowują oni wspomnień z przeszłości i nie antycypują przyszłości ${ }^{25}$. Trauma związana z doświadczeniem ludobójstwa jest — w bardziej ogólnej perspektywie — destrukcją chronologii i negacją historii jako ciągłości w czasie ${ }^{26}$.

Elementem stereotypu Romów, rozpowszechnionego w europejskiej kulturze głównego nurtu od początku epoki nowoczesnej, jest przekonanie, że tworzą oni „lud bez historii”, który żyje w „wiecznym teraz”, a tym samym należy bardziej do porządku natury niż społeczeństwa ${ }^{27}$. Pogląd ten umocnił się w XIX wieku wraz z rozwojem kolonializmu i jego rasistowskich legitymizacji, umożliwiając umieszczenie „Cyganów” na tym samym poziomie co inne rzekomo niehistoryczne ludy należące do świata skolonizowanego przez Europę i potraktowanie ich jako „rasy”28. Powstające w tym samym czasie interpretacje romskiej tożsamości dzieliły ów pogląd, przypisując Romów do świata natury, charakteryzującego się całkowicie odmienną czasowością niż historyczny świat nie-Romów ${ }^{29}$. Takie wyobcowanie temporalne było odpowiedzialne za obraz Romów jako radykalnie innych, gdyż żyjących w ,innym czasie" ${ }^{30}$, reprezentującym w europejskiej teraźniejszości jakieś wcześniejsze „stadia rozwojowe”. Romowie padli więc ofiarą „różnicującego pozbawiania historii” ${ }^{31}$, które często stawało się udziałem ludów

25 S.J. Brison, Trauma narratives and the remaking of the self, [w:] Acts of Memory. Cultural Recall in the Present, red. M. Bal, J. Crewe, L. Spitzer, Hanover-London 1999, s. 43.

26 E. Van Alphen, Symptoms of discursivity: Experience, memory, and trauma, [w:] Acts of Memory..., s. 35.

27 K. Trumpener, The time of the Gypsies. A "people without history" in the narratives of the west, „Critical Inquiry” 1992, nr 18.

28 M.P. Fitzpatrick, Purge the Empire: Mass Expulsions in Germany 1871-1914, Oxford 2015, s. 179 .

29 W. Wippermann, ,, Wie die Zigeuner”. Antisemitismus und Antiziganismus im Vergleich, Berlin 1997, s. 113 .

30 J. Fabian, Time and the Other. How Anthropology Makes Its Object, New York 1983.

31 Z. Bauman, Mortality, Immortality and Other Life Strategies, Cambridge 1992. 
podbitych i zdominowanych ${ }^{32}$ i które sprawiło, że ich własna historia została uciszona, a związki łączące ją z historią społeczeństw większościowych - wyma$z^{3} e^{33}$. To wykluczenie z (zachodniej) historii zostało następnie zaprezentowane jako rezultat wyboru dokonanego przez samych Romów na podstawie rzekomych specyficznych wartości ich kultury. Doskonałą ilustracją takiego stanowiska są poglądy Emila Ciorana, który w swej filozofii idealizował Romów jako tych, którzy odmówili „upadku z wieczności w Czas” i odrzucili historyczność, a jednocześnie uważał ich za prymitywną rasę barbarzyńców ${ }^{34}$.

Stereotyp ten stosowano również do sytuacji, w których Romowie stawali się istotnymi aktorami historii, w tym na przykład ofiarami nazistowskiego ludobójstwa, a także do ich pamięci tych wydarzeń. Twierdzono więc, że zasłona milczenia, która rzekomo spowijała nazistowskie prześladowania, była produktem romskiej kultury, jakoby niezdolnej do rejestracji ważnych wydarzeń historycznych, gdyż nieoperującej kategorią historyczności. Jak argumentowałem gdzie indziej ${ }^{35}$, analiza doświadczenia Romów ocalałych z Zagłady i — bardziej ogólnie - mechanizmów romskiej pamięci zbiorowej pozwala obalić to stwierdzenie i zinterpretować je jako składnik procesu wykluczania przez stereotypizację, której Romowie zostali poddani.

Romowie pamiętają swe cierpienia, lecz miewają problemy z komunikowaniem swoich wspomnień innym grupom romskim, ponieważ miały one często zupełnie inne doświadczenia, a także nieromskiej większości, gdyż ta najczęściej nie jest po prostu zainteresowana losem Romów ${ }^{36}$. Poza tym Romowie do niedawna nie mieli dostępu do środków tworzenia i rozpowszechniania wiedzy o przeszłości. Czasami wprawdzie mogli wyciszać swe wspomnienia, nie dlatego jednak, że byli uwarunkowani swą rzekomo ahistoryczną kulturą, lecz z powodu psychologicznych mechanizmów przywracania poczucia bezpieczeństwa, powszechnych w wypadku ocalałych. Jeśli temporalny i mnemoniczny horyzont Romów ocalałych z Zagłady kurczy się (co bynajmniej nie musi być regułą), to dzieje się tak nie dlatego, że są oni Romami (to znaczy z powodu posiadania przez nich specyficznej kultury), lecz ponieważ są ocalałymi, czyli ludźmi, którzy przeżyli Zagładę i mogą stosować zapomnienie jako mechanizm obronny.

32 M.R. Trouillot, Silencing the Past. Power and the Production of History, Boston 1995.

33 E.R. Wolf, Europe and the People without History, Berkeley-Los Angeles 1982.

34 I. Kania, Cioran, albo o anachronizmie madrości, [w:] E. Cioran, Zły demiurg, przeł. I. Kania, Kraków 1995, s. 131; E.M. Cioran, All Gall is Divided, New York 1999, s. 122; V. Nicolae, H. Slavik, Being "Gypsy": The Worst Social Stigma in Romania, European Roma Rights Centre 2003, www.errc.org/article/being-a-gypsy-the-worst-social-stigma-in-romania/1385 (dostęp: 8.02.2016). Szerzej na ten temat piszę w: S. Kapralski, Milczenie - pamięć - tożsamość. Fantazmat „Cygana” i ambiwalencja nowoczesności, „Ethos” 29, 2016, nr 1 (113).

35 S. Kapralski, Naród z popiołów. Pamięć zagłady a tożsamość Romów, Warszawa 2012.

36 A. Mirga, Roma genocide: Historic and symbolic meanings for collective memory and identity, [w:] Education for Remembrance of the Roma Genocide. Scholarship, Commemoration and the Role of Youth, red. A. Mirga-Kruszelnicka, E. Acuña, P. Trojański, Kraków 2015. 
Stosując przyjętą w tej pracy terminologię, możemy przedstawić sytuację Romów jako problematyczną relację między dwiema genealogiami pamięci, między mneme i anamnesis. Z powodu zróżnicowania doświadczeń i niespójności losu oddolny proces przekształcania indywidualnych wspomnień w przedmiot komunikacji, wzmacnianej następnie przez kulturowe instytucje wytwarzające pamięć zbiorową, był zbyt słaby, aby zapewnić romskiej pamięci wystarczającą energię. Z kolei niska pozycja społeczna Romów po wojnie i brak kontroli nad instytucjami podtrzymującymi pamięć kulturową pozbawiły ich narzędzi służących organizowaniu pamięci społecznej (komunikacyjnej) i wzmacnianiu indywidualnych wspomnień, co sprawiło, że odgórne mechanizmy kształtowania pamięci okazały się nieskuteczne. Sytuacja ta zaczęła się przekształcać dopiero w drugiej połowie XX wieku wraz ze zmianami warunków życiowych społeczności romskich i początkiem romskiego ruchu politycznego.

\section{Romskie tożsamości i pamięć niedyskursywna}

W poprzednich częściach tej pracy twierdziłem, że sposób, w jaki Romowie pamiętają, jest uwarunkowany raczej sytuacją społeczną poszczególnych grup romskich niż ich kulturą. W tym miejscu chciałbym bardziej szczegółowo przedstawić relację między kulturą a społeczeństwem w różnych konstruktach romskiej tożsamości i wpływ, jaki ta relacja może mieć na powstawanie niedyskursywnych form pamięci.

Kultura romska jest w przyjętej tu perspektywie postrzegana jako byt realny, który jednakże nie jest aktywny per se, lecz tworzy zasób elementów kulturowych, które w pewnych sytuacjach są aktywowane, w innych zaś — pomijane. Oczywiście nie oznacza to, że kultura w ogóle nie wywiera żadnego wpływu. Charakteryzuje się ona inercją, która sprawia, że pewne jej składniki są łatwiejsze do aktywowania i zastosowania w konstruktach tożsamościowych niż inne. Jednakże w przeciwieństwie do perspektywy „kulturalistycznej”, dominującej w tradycyjnej romologii, uważam że tym, co aktywizuje elementy kulturowe, nie jest ich immanentna siła oddziaływania, lecz konstelacja interesów politycznych, ekonomicznych i społecznych, która wprawia w ruch wartości kulturowe jako swe narzędzia.

Takie podejście do relacji między czynnikami kulturowymi a społecznymi jest zakorzenione $\mathrm{z}$ jednej strony $\mathrm{w}$ ogólnej teorii systemów, $\mathrm{z}$ drugiej zaś w niektórych kierunkach antropologii kulturowej. Pierwsza głosi, że granice międzygrupowe tworzą się w procesie różnicowania systemu („my”) i otoczenia („oni”), a różnica ta zostaje następnie odtworzona wewnątrz systemu. Jeśli zastosujemy to podejście do kwestii romskiej tożsamości, możemy stwierdzić, że podstawowa różnica między Romami („,system”) a nie-Romami („otoczenie”) odtwarza się wewnątrz systemu (,Romowie”) jako na przykład różnica między 
„czystym” a „skalanym”37 (w tych grupach, które uznają tę różnicę) lub między męskimi a żeńskimi rolami płciowymi. „Skalane” i „kobieta” są w tym ujęciu wewnątrzsystemowymi odpowiednikami otoczenia i potencjalnym źródłem zagrożenia, podczas gdy „czyste” i „mężczyzna” reprezentują właściwą istotę romskości, tak jak jest ona pojmowana w bardziej tradycyjnych społecznościach, których członkowie mogą preferować postrzeganie romskich tożsamości zbiorowych ,jako ustalonych, trwałych i zakładających homogeniczność, a tym samym spójność grupy, z której może ona czerpać swą siłę"38.

Perspektywę teorii systemów uzupełnia podejście antropologiczne Mary Douglas $^{39}$, w którym kulturowa koncepcja ludzkiego ciała koduje kluczowe właściwości stosunków społecznych charakteryzujących daną grupę. Kontrola ciała (fizjologii, prokreacji, seksualności) może być w tym ujęciu rozumiana jako kod symboliczny (substytut) kontroli granicy społecznej, gdyż ludzkie ciało to metafora społeczności, a kontrola granic ciała (zwłaszcza jego otworów) jest odpowiednikiem kontroli granic społecznych, zwłaszcza „punktów przejścia”, w których potencjalnie dokonuje się wkroczenie świata zewnętrznego do wnętrza społeczności. Można stąd wyprowadzić wniosek, że im więcej środków ostrożności i obaw związanych z ciałem ludzkim znajdujemy w danej kulturze, tym bardziej jej uczestnicy są skoncentrowani na obronie granicy społecznej oddzielającej ją od innych społeczności, i tym mniej są ją w stanie efektywnie obronić. Mówiąc bardziej ogólnie — gdy nie można kontrolować granicy między systemem a otoczeniem, członkowie grupy stanowiącej system mogą kompensować sobie tę niemożność wzmocnioną kontrolą tego, co kontrolować są w stanie, czyli wewnętrznych dychotomii kulturowych.

Jeśli zastosować to rozumowanie do kontekstu romskiego życia, zobaczymy, jak zauważył Michael Stewart ${ }^{40}$, że kulturowo określone podziały płciowe nie dotyczą zasadniczo relacji między kobietami a mężczyznami — symbolizują one negację biologii (reprezentowanej przez kobietę) i afirmację stosunków społeczno-kulturowych (reprezentowanych przez mężczyznę), które determinują romską tożsamość. Poprzez kontrolę kobiecego ciała i seksualności, jak też przez separację ciał kobiecych i męskich, Romowie negują lub deprecjonują ich udział w reprodukcji biologicznej i czczą reprodukcję społeczną/kulturową. W ten sposób

37 Wiele grup romskich, choć nie wszystkie, dzieli świat na sferę zjawisk bezpiecznych (,,czyste”) i zagrażających (,skalane”). „Romskość” polega na zapobieganiu mieszaniu się tych dwóch porządków, co wiąże się ze skomplikowanym systemem nakazów, zakazów, tabu i rytuałów.

38 J.M. Jasper, A. McGarry, Introduction. The identity dilemma, social movements, and contested identity, [w:] The Identity Dilemma. Social Movements and Collective Identity, red. A. McGarry, J.M. Jasper, Philadelphia 2015, s. 3.

39 M. Douglas, Purity and Danger. An Analysis of the Concepts of Pollution and Taboo, London 1966.

40 M. Stewart, The Time of the Gypsies, Colorado 1997, s. 205. 
redukują wagę swoich ciał biologicznych, które czynią ich zależnymi od nieromskiego świata i wystawionymi na jego wpływy.

Nieromskie otoczenie, zazwyczaj wrogo wobec Romów nastawione, może kontrolować i represjonować biologiczne ciała Romów, na przykład przez ograniczenie wolności poruszania się, więzienie, ataki fizyczne, sterylizację czy eksterminację. Nie-Romowie mają władzę kontroli granicy oddzielającej Romów od nich, Romowie zaś nie są zazwyczaj w stanie skutecznie jej bronić. Co więcej, żyjąc w stanie symbiotycznej zależności od nieromskiego świata, Romowie muszą tę granicę przekraczać, wchodząc na nieromskie terytorium w celu zapewnienia sobie środków do życia, co dodatkowo naraża ich na dyskryminacyjne praktyki nie-Romów. O ile jednak nie-Romowie mogą uczynić wiele zła biologicznym ciałom Romów, o tyle nie mają dostępu do romskiego ciała społecznego, na które składa się wewnętrzna organizacja życia, chroniona przez pojęcia kulturowe, za pomocą których Romowie podtrzymują swoją tożsamość. Można tu zastosować perspektywę antropologii politycznej Ernsta Kantorowicza ${ }^{41}$ i powiedzieć, że ciało biologiczne nieuchronnie przemija, natomiast romskie ciało społeczno-kulturowe jest nieśmiertelne.

Społeczna konstrukcja relacji między płciami kulturowymi stanowi więc w tym ujęciu funkcję społecznego położenia grupy. Grupa, której istnienie jest zagrożone przez stosunki z wrogim otoczeniem, koduje opozycję binarną „,myoni” (która ma zasadnicze znaczenie dla tożsamości grupowej) za pomocą opozycji „męskie-żeńskie”. Następnie rytualne mechanizmy postępowania z drugą opozycją stwarzają przekonanie, że również ta pierwsza zostanie podtrzymana, a tym samym że granica oddzielająca Romów od nie-Romów będzie chroniona.

Prezentowane tu podejście wywodzi się też z koncepcji Fredrika Bartha ${ }^{42}$, zgodnie z którą to nie substancja kulturowa determinuje tożsamość grupową, lecz granice społeczne kształtujące zawarte w nich treści kultury. Romska tożsamość jest tu więc rozumiana jako podtrzymywanie granicy społecznej, która ochrania romską ,przestrzeń społeczną, ukształtowaną zgodnie z romską etyką stosunków wzajemnych"43. W tym podejściu kultura jest zmienną zależną — możemy ją wyjaśnić jako rezultat procesów budowania przez Romów relacji z ich otoczeniem i jako zasób, który jest w tych procesach wykorzystywany.

Oznacza to, że możemy ująć stosunek między romskim systemem kulturowym a systemem społecznym jako relację podwójnego kodowania lub podwójnej ekspresji. Społeczne relacje między Romami a nie-Romami wyrażają się (są kodowane) za pomocą opozycji kulturowych, a relacje między konstruktami kulturowymi wyrażają się (są kodowane) w systemie społecznym. W szczególności gdy

41 E.H. Kantorowicz, The King 's Two Bodies: A Study in Mediaeval Political Theology, Princeton 1957.

42 F. Barth, Ethnic Groups and Boundaries, Boston 1969.

43 M. Stewart, The Time of the Gypsies..., s. 28. 
Romowie nie są w stanie kontrolować relacji z nie-Romami na własnych warunkach, lęki związane z niemożnością kontroli granicy społecznej mogą prowadzić do zwiększonych wysiłków na rzecz kontrolowania tego, co kontrolować się da: relacji między elementami romskiej kultury, na przykład opozycji „męskie-żeńskie". Z kolei gdy ta ostatnia opozycja ulega osłabieniu (na przykład w wyniku procesu akulturacji), wówczas lęki związane z tym procesem mogą być wyrażone w wysiłkach na rzecz uszczelnienia granicy społecznej i zredukowania kontaktów międzygrupowych.

Tak rozumiany proces budowania tożsamości ma istotny wymiar historyczny. Relacje między elementami kulturowymi, na przykład ufundowanie tożsamości w kulturowej opozycji „męskie-żeńskie”, nie jest rezultatem działania prymordialnych wartości kulturowych, lecz reakcją na brak kontroli granicy społecznej w konkretnych sytuacjach historycznych. Jedną z takich sytuacji były nazistowskie prześladowania i ludobójstwo. Nazistowska polityka wobec Romów zniszczyła lub poważnie osłabiła romskie mechanizmy kontrolowania granicy społecznej własnej grupy. Co więcej, radykalne rozwiązania zastosowane wobec Romów, takie jak pozbawienie praw obywatelskich, uwięzienie w obozach koncentracyjnych, przymusowa sterylizacja i masowa eksterminacja, zagroziły również kulturowym zasadom romskiego życia, które w warunkach prześladowań nie zapewniały już poczucia bezpieczeństwa, a czasami musiały być zawieszone, na przykład w obozach, gdzie niemożliwe było życie zgodne z romskim systemem wartości ${ }^{44}$. W konsekwencji, jak pisze Kirsten Martins-Heuß, w III Rzeszy „każdy z ocalałych dorosłych Cyganów stracił swój honor" ${ }^{45}$. Należy tu podkreślić, że w tym konkretnym przypadku załamał się mechanizm kompensacyjny — kryzys mechanizmów obrony granicy zewnętrznej nie mógł zostać zrównoważony umocnieniem wewnętrznych regulacji kulturowych, one również uległy załamaniu ${ }^{46}$.

Traumy związane z nazistowskimi prześladowaniami i sytuacją powojenną wywarły istotny wpływ na proces odbudowy wewnętrznych dystynkcji kulturowych, a tym samym na pozycję kobiet $w$ grupach niemieckich Sinti ${ }^{47}$ :

Cyganie-mężczyźni - pisze Martins-Heuß - musieli się zmierzyć z tym, co zewnętrzny świat uczynił im w czasach nazistów, i w związku z tym przepracować te elementy własnej kultury, które reprezentowały i ucieleśniały świat [...]: mianowicie swoje kobiety. Degradacja doświad-

44 Zob. L. Mróz, Niepamięć nie jest zapominaniem. Cyganie-Romowie a Holokaust, „Przegląd Socjologiczny" 49, 2000, nr 2.

45 K. Martins-Heuß, Reflections on the collective identity of German Roma and Sinti (Gypsies) after national socialism, „Holocaust and Genocide Studies” 4, 1989, nr 2, s. 207.

46 Szerzej na ten temat zob. S. Kapralski, Doświadczenie zagłady i poczatki samoorganizacji niemieckich Sinti, „Studia Romologica” 2015, nr 8.

47 „Sinti” to nazwa własna ludzi, których przodkowie przybyli na ziemie niemieckie w XV wieku. Odczuwają pokrewieństwo z tymi, którzy określają się jako Romowie, i łączy ich z nimi wiele charakterystyk etnicznych. Są jednak przywiązani do własnego samookreślenia i nie chcą być nazywani Romami. 
czana przez Romów i Sinti wskutek nazistowskiej polityki rasowej i konsekwencje tego doświadczenia przyczyniły się do powstania wśród ofiar i ich dzieci głębokiego i nawet dziś jeszcze zinternalizowanego poczucia niższości. Aby móc walczyć z tym permanentnym ciężarem pogardy do samego siebie, mężczyźni odreagowują swe upokorzenie na kobietach ${ }^{48}$.

Podejście Martins-Heuß sugeruje, że patriarchalny charakter społeczności Romów i Sinti oraz kulturowa konstrukcja kobiety jako źródła zmazy, przed którą trzeba się bronić za pomocą kontrolowania kobiecej seksualności i utrzymywania kobiet $\mathrm{w}$ podporządkowanej pozycji, nie jest rezultatem reprodukcji idiomu kulturowego i tradycji odziedziczonej z przeszłości. Zjawiska te mogą też być okolicznościowymi, historycznie uwarunkowanymi reakcjami na zniszczenie mechanizmu kontrolowania granicy społecznej Romów w III Rzeszy i później. Martins-Heuß twierdzi na przykład, że na początku XX wieku wśród Sinti mężczyźni i kobiety siadywali przy tym samym stole jak równi, natomiast po 1945 roku zwyczajem stało się rozdzielanie mężczyzn i kobiet, co zaczęło być z czasem traktowane jako zachowanie wyznaczone przez tradycję $e^{49}$.

Opozycja „męskie-żeńskie”, będąca jednym z kulturowych elementów charakteryzujących tożsamość „tradycyjnych” Romów, może być zatem postrzegana jako względnie nowy rezultat konkretnych relacji społecznych, który następnie przeszedł proces retradycjonalizacji i funkcjonuje w świadomości zarówno Romów, jak i badających ich uczonych jako odwieczna, pierwotna wartość kulturowa. Wniosek ten współbrzmi z rosnącą autorefleksją antropologii:

Obecnie staje się coraz bardziej jasne — pisze Arjun Appadurai — że w wielu przypadkach gdy antropolodzy wierzą, że obserwują i analizują pierwotne i pradawne systemy, w rzeczywistości mają do czynienia z produktami niedawnych $[\ldots]$ interakcji ${ }^{50}$.

Takie podejście nie oznacza, że wszystkie romskie tradycje są stosunkowo niedawnymi odpowiedziami na położenie społeczne Romów. Implikuje ono jednak, że aby zrozumieć konkretny aspekt romskiej kultury, musimy wziąć pod uwagę interakcję kultury jako historycznie zakumulowanego zasobu znaczeń i konkretnych, historycznie ukształtowanych form relacji między Romami a nie-Romami, w których to te ostatnie są odpowiedzialne za dynamikę kulturową.

Czas nazistowskich prześladowań Romów był okresem, w którym romskie umocnienia granicy oddzielającej Romów od nie-Romów zostały brutalnie zniszczone. Jednocześnie, z powodu warunków życia w opresyjnym państwie, Romowie i Sinti nie byli w stanie przekodować lęków związanych ze zniszczeniem granicy społecznej na wewnętrzną sferę kultury. Podjęli jednak to zadanie po woj-

48 K. Martin-Heu $\beta$, op. cit., s. 208.

49 Ibidem, s. 211.

50 A. Appadurai, Putting hierarchy in its place, ,Cultural Anthropology” 13, 1988, nr 1, s. 3839. Podobnego zdania jest Jack Goody, według którego społeczności nieposiadające pisma zmieniają swe „niezmienne tradycje”, lecz nie są w stanie tej zmiany odnotować i często twierdzą, że nie zmieniają się w ogóle; zob. idem, Mit, rytuat i oralność, przeł. O. Kaczmarek, Warszawa 2012. 
nie. Aczkolwiek również w nowej rzeczywistości nie mogli kontrolować relacji z nie-Romami według własnych zasad, to jednak granica ta nie była już tak brutalnie naruszana przez świat zewnętrzny, a przede wszystkim Romowie odzyskali kontrolę nad swym ciałem społeczno-kulturowym i wytworzyli wewnątrz własnej grupy granicę, którą mogli skutecznie kontrolować, używając narzędzi kulturowych, w tym kulturowych konstruktów płci. Kontrola ta umożliwiła im odzyskanie poczucia podmiotowości i integralności, osłabionych w wyniku nazistowskich prześladowań i sytuacji w powojennych Niemczech.

Z punktu widzenia badań nad pamięcią mamy tu szczególny przypadek pamięci niedyskursywnej, zapisanej w stosunkach między płciami i w naturze ich kulturowych konstrukcji. Konkretna postać tych stosunków, poddana retradycjonalizacji, stanowi zapis traumatycznych doświadczeń, które są represjonowane na poziomie indywidualnych wspomnień i których się nie komunikuje, gdyż związane są z poczuciem wstydu.

\section{Model i rzeczywistość - przypadek trzech grup romskich}

W tym podrozdziale chciałbym zastosować przedstawiony model teoretyczny do interpretacji danych pochodzących z przeprowadzonych w 2013 roku wywiadów z działaczkami romskich organizacji, należącymi do trzech grup: Polska Roma, polscy Romowie Karpaccy i Romowie słowaccy ${ }^{51}$. Polska Roma jest grupą, która prowadziła życie wędrowne (lub półwędrowne) aż do lat siedemdziesiątych XX wieku. Jej członkowie często określają się jako żyjący według systemu wartości i kodeksu zachowania opartego na wizji świata podzielonego na sferę czystą i nieczystą. Polscy Romowie Karpaccy (nazywani Bergitka przez członków Polskiej Romy i niektórych badaczy) składają się z wielu luźno z sobą powiązanych wspólnot, od wieków osiadłych w karpackich wioskach. Członkowie tej grupy po II wojnie światowej migrowali do miast, wykorzystując możliwości stwarzane przez komunistyczną industrializację i podejmując pracę w przemyśle, podczas gdy Polska Roma preferowała samozatrudnienie w tradycyjnych romskich profesjach oraz handel. Dialekt Romów Karpackich różni się od dialektu Polskiej Romy, aczkolwiek członkowie tych grup mogą się z łatwością komunikować. Romowie Karpaccy nie mają tradycji nomadycznej i nie posiadają kodeksu opartego na podziale świata na „czyste” i ,skalane”. Z tego ostatniego powodu są przez Polską Romę postrzegani jako właśnie „skalani” i nie do końca prawdziwi Romowie, co ma wpływ na wzajemne stosunki członków tych grup.

51 Szerzej na temat tych badań i ich wyników zob. S. Kapralski, Sytuacja kobiet romskich w Polsce i na Stowacji z punktu widzenia romskich aktywistek. Wstepne rezultaty badania pilotażowego, „Studia Romologica” 2014, nr 7. 
Badani przez nas Romowie słowaccy są kulturowo, językowo i społecznie bliscy polskim Romom Karpackim. Tworzą społeczność osiadłą, która w przeszłości doświadczyła polityki przymusowej asymilacji ze strony monarchii austro-węgierskiej. Obie te grupy mówią tą samą odmianą języka romani, aczkolwiek wersja, którą posługują się polscy Romowie Karpaccy, jest obecnie pod dużym wpływem języka polskiego, natomiast ta, którą mówią Romowie słowaccy słowackiego. Romowie słowaccy również nie mają kodeksu opartego na wizji podzielonego świata, z wyjątkiem pewnych pozostałości kiedyś obowiązujących wartości, które zanikły między innymi w wyniku przymusowej asymilacji, a obecnie istnieją w szczątkowej postaci jako psychologiczna dyrektywa postępowania, nie zaś jako metafizyczna zasada leżąca u podstaw wizji świata ${ }^{52}$. Podobnie jak Romowie w Polsce słowaccy Romowie są głównie katolikami, choć ostatnio, inaczej niż w Polsce, bardzo aktywne są wśród nich Kościoły zielonoświątkowe ${ }^{53}$.

Można więc powiedzieć, że w perspektywie kulturowej członkowie grupy Polska Roma różnią się od polskich Romów Karpackich i Romów słowackich, podczas gdy członkowie tych dwóch ostatnich grup są kulturowo podobni. Z kolei z socjologicznego punktu widzenia wszystkie trzy grupy mają podobne relacje $\mathrm{z}$ otoczeniem, aczkolwiek polscy Romowie Karpaccy i Romowie słowaccy mają dłuższą tradycję stałych interakcji z nie-Romami z powodu osiadłego trybu życia i bycia przedmiotem przymusowej asymilacji. Jednocześnie jednak Polska Roma i polscy Romowie Karpaccy zbliżają się do siebie, gdyż żyją w jednym kraju i traktowani są w taki sam sposób przez władze i większość społeczną.

$\mathrm{Z}$ powodu istniejącej różnicy kulturowej można by oczekiwać, że postawy członków grupy Polska Roma wobec ważnych aspektów romskiego życia będą odmienne od postaw polskich Romów Karpackich i Romów słowackich, podczas gdy postawy członków dwóch ostatnich grup będą do siebie podobne. Moglibyśmy na przykład oczekiwać, że postawy naszych rozmówczyń odnośnie do edukacji dziewczynek romskich, patriarchalnego charakteru romskich społeczności i form pomocy, jakich kobiety romskie mogą się spodziewać, zwłaszcza w dziedzinie praw reprodukcyjnych i edukacji seksualnej, będą podobne wśród polskich Romów Karpackich i Romów słowackich. Będą zaś one różne w wypadku bardziej konserwatywnej Polskiej Romy. Tymczasem okazało się, że poglądy działaczek z grupy Polska Roma i tych należących do polskich Romów Karpackich są niemal identyczne i zdecydowanie odmienne od poglądów Romek słowackich. W pierwszym przypadku dominuje zrezygnowana akceptacja patriarchalnych stosunków społecznych i przekonanie, że „nic się nie da zrobić” (choć Romki Karpackie podkreślają swą większą od kobiet Polskiej Romy niezależność finansową, a obie grupy doceniają potrzebę edukacji dziewcząt). Jest to szczególnie istotne, jeśli idzie

52 L. Tcherenkov, S. Laederich, The Rroma, t. 2. Traditions and Texts, Basel 2004, s. 564.

53 T. Podolinská, T. Hrustič, Religion as Path to Change? The Possibilities of Social Inclusion of the Roma in Slovakia, Bratislava 2011. 
o kwestię edukacji seksualnej, planowania rodziny i wiedzy o antykoncepcji. Polskim działaczkom romskim, niezależnie od przynależności grupowej, nie przychodzi nawet do głowy, że sprawy te mogłyby stać się obszarem działania romskich organizacji - byłaby to ich zdaniem niedopuszczalna ingerencja w wyłączne prerogatywy rodziny. Tymczasem dla Romek słowackich jest to oczywista sfera działania romskich organizacji pozarządowych, zwłaszcza kobiecych i tych, w których kobiety odgrywają większą rolę, a także służby zdrowia i polityki społecznej.

Można powiedzieć, że kobiety należące do kulturowo podobnych grup mogą inaczej postrzegać swoją sytuację i poszukiwać odmiennych rozwiązań, podczas gdy kobiety należące do grup kulturowo różnych mogą mieć jednakowe poglądy na pewne zagadnienia i poszukiwać podobnych rozwiązań. Sytuacja romskich kobiet zależy zatem bardziej od relacji łączącej ich grupy z otoczeniem niż od wartości kulturowych charakteryzujących te grupy. Na przykład podobieństwa między kulturowo różnymi grupami, takimi jak Polska Roma i polscy Romowie Karpaccy, mogą być interpretowane jako rezultat interakcji z podobnym, bardziej niż na Słowacji konserwatywnym, otoczeniem kraju, w którym żyją. Ponadto romski sektor pozarządowy wydaje się lepiej rozwinięty na Słowacji niż w Polsce, co czyni mocniejszą jego pozycję w stosunku do tradycyjnych struktur romskich społeczności.

W duchu prezentowanej tu koncepcji możemy jednak również odwołać się do odmiennych pamięci niedyskursywnych, poprzez które na romską tożsamość działają zakumulowane w kulturze i strukturze społecznej doświadczenia historyczne. Konkretnie rzecz ujmując, aby wyjaśnić naszkicowaną różnicę stanowisk członków dwóch kulturowo podobnych grup (polskich Romów Karpackich i Romów słowackich), powinniśmy odwołać się do odmiennych doświadczeń polskich i słowackich Romów w czasie II wojny światowej.

W typologii zaprezentowanej przez Helen Fein ${ }^{54}$ i zastosowanej do badań nad prześladowaniem Romów przez Brendę Davis Lutz i Jamesa M. Lutza ${ }^{55}$ Polska i Słowacja należały do dwóch całkowicie odmiennych obszarów nazistowskiego panowania. Polska, pokonana przez armię niemiecką we wrześniu 1939 roku, była następnie okupowana przez hitlerowskie Niemcy (i do 1941 roku przez ZSRR, kolaborujący wówczas z III Rzeszą). Część terytorium Polski została włączona do Rzeszy Niemieckiej, pozostały obszar stanowił tak zwane Generalne Gubernatorstwo - teren okupowany, zarządzany przez niemieckie władze okupacyjne. Słowacja zaś ogłosiła niepodległość w marcu 1939 roku, kiedy została ustanowiona Republika Słowacka - nowe państwo, sprzymierzone z hitlerowskimi Niemcami. Stanowiło to o radykalnej różnicy co do sytuacji Romów w obu krajach. Na terenie Polski naziści stosowali bezpośrednio swą antyromską politykę, obejmującą de-

${ }^{54}$ H. Fein, Accounting for Genocide: National Responses and Jewish Victimization during the Holocaust, Chicago 1979.

55 B.D. Lutz, J.M. Lutz, op. cit. 
portacje do obozów śmierci i masowe rozstrzeliwania. Natomiast w Republice Słowacji nie planowano ludobójstwa Romów. Antyromska polityka była realizowana przez lokalną słowacką administrację, która wysyłała Romów do specjalnych brygad roboczych, budujących drogi i linie kolejowe, lub do obozów internowania. W 1944 roku, po wybuchu słowackiego powstania narodowego, niektóre obozy pracy zostały przekształcone w obozy koncentracyjne, w których pewna liczba Romów zmarła z powodu chorób lub została rozstrzelana. Śmierć przez rozstrzelanie była często losem Romów podejrzanych o udział w powstaniu.

W rezultacie tych różnic w Polsce zamordowano o wiele więcej Romów niż na Słowacji i był to zdecydowanie większy odsetek romskiej populacji Polski niż odsetek romskich ofiar na Słowacji. To możemy powiedzieć z całą pewnością, niezależnie od liczb, które są przybliżone i bardzo się różnią w zależności od tego, kto je podaje. Jeśli chodzi o Polskę, to Lutz i Lutz ${ }^{56}$ wskazują, że zginęło około 28 tysięcy Romów (co stanowiło według nich około 60\% przedwojennej romskiej populacji kraju), podczas gdy na Słowacji życie straciło tysiąc osób spośród 80 tysięcy Romów, którzy żyli na terenie Słowacji przed wojną. Liczby te zostały zaczerpnięte z pierwszego wydania książki Donalda Kenricka i Grattana Puxona $^{57}$, zawierającego rozliczne błędy i opartego na słabej bazie źródłowej. W drugim wydaniu ${ }^{58}$ autorzy szacują liczbę Romów zamordowanych w Polsce na 13 tysięcy, co miało stanowić 25\% Romów żyjących w kraju przed wojną. Michael Zimmermann zaś twierdzi, że romskich ofiar było w Polsce jeszcze mniej około 8 tysięcy, co jednak jego zdaniem miało stanowić niemal jedną trzecią całej społeczności polskich Romów ${ }^{59}$. Jeśli idzie o Słowację, to drugie wydanie książki Kenricka i Puxona podaje, że ,jedynie kilkuset spośród całej romskiej populacji, szacowanej na ponad 100 tysięcy, zginęło z rąk faszystów"60.

Bez względu na brak zgody odnośnie do liczby ofiar i rozmiarów romskich społeczności w obu krajach, musimy przyjąć, że między historycznym doświadczeniem polskich i słowackich Romów była spora różnica. Różny los tych społeczności częściowo potwierdza ogólną tezę, zgodnie z którą tam, gdzie niemieccy naziści sprawowali władzę bezpośrednio, Romowie byli najbardziej zagrożeni całkowitą eksterminacją, niemal tak samo jak Żydzi 61 . Na terenach administrowanych przez państwa sprzymierzone z hitlerowskimi Niemcami ,władze w Berlinie musiały negocjować działania skierowane przeciwko wybranym celom, zamiast po prostu wydać rozkaz rozpoczęcia zabijania lub deportacji”62. Państwa

56 Ibidem, s. 349.

57 D. Kenrick, G. Puxon, The Destiny of Europe's Gypsies, London 1972.

58 D. Kenrick, G. Puxon, Gypsies under the Swastika..., s. 123.

59 M. Zimmermann, Rassenutopie und Genozid. Die nationalsozialistische Lösung der Zigeunerfrage, Hamburg 1996, s. 283.

60 D. Kenrick, G. Puxon, Gypsies under the Swastika..., s. 123.

61 B.D. Lutz, J.M. Lutz, op. cit., s. 354.

62 Ibidem, s. 351. 
sprzymierzone, z wyjątkiem Chorwacji, nie były z rozmaitych, głównie ekonomicznych, powodów zainteresowane prześladowaniem Romów, dlatego też Romowie żyjący na ich terytoriach mieli większą szansę przeżycia niż ci poddani bezpośredniej władzy niemieckich nazistów.

W rezultacie zróżnicowanego traktowania w czasie II wojny światowej doświadczenie destrukcji, upokorzenia i zagrożenia dla egzystencji grupowej było o wiele bardziej powszechne wśród Romów polskich niż słowackich. Ci pierwsi mieli tym samym o wiele istotniejsze powody, by w kompensacyjny sposób umacniać wewnętrzne granice kulturowe, w tym podział na „męskie-żeńskie”, kodując w ten sposób lęk przed zagrożeniem egzystencjalnym (zniszczeniem zewnętrznej społecznej granicy grupy) jako strach przed naruszeniem wewnętrznej granicy między odseparowanymi od siebie elementami kultury. Ta różnica doświadczenia historycznego pozwala zrozumieć występowanie podobieństw między kulturowo różnymi grupami polskich Romów i różnic między kulturowo podobnymi polskimi Romami Karpackimi i Romami ze Słowacji.

Oczywiście doświadczenie historyczne i mechanizmy radzenia sobie z nim nie mogą wyjaśnić wszystkiego. Aby otrzymać pełniejszy obraz, musielibyśmy wziąć pod uwagę różnice polityki wobec Romów w komunistycznej Polsce i Czechosłowacji, różny stopień asymilacji, odmienną sytuację ekonomiczną poszczególnych grup romskich w obu krajach, odmienny charakter nieromskiego otoczenia i różny stopień rozwoju romskiego sektora pozarządowego. W wypadku polskich Romów Karpackich ważne jest również to, że — inaczej niż w przypadku Romów słowackich — w ich otoczeniu funkcjonuje dość konserwatywna grupa romska (Polska Roma) o dużym prestiżu, której członkowie uważają się za „lepszych Romów", lepiej realizujących ideały romskiego życia. Może to powodować, że niektórzy z Romów Karpackich mogą chcieć „równać do najlepszych” i unikać działań, które mogłyby się w ich „grupie odniesienia” nie spodobać.

Niemniej jednak prezentowana tu hipoteza mówiąca, że romskie tożsamości przybierają określone formy nie dlatego, że Romowie mają taką, a nie inną kulturę, lecz w rezultacie historycznie zmiennych relacji między granicą społeczną oddzielającą Romów od nie-Romów a romskimi zasobami kulturowymi, które to relacje akumulują się w postaci niedyskursywnej pamięci traumatycznej, wydaje się warta dalszych badań.

Konkluzja

W artykule przedstawiłem pewną koncepcję pamięci zbiorowej, która posłużyła do wskazania problemów, jakie społeczności romskie mają z budowaniem wspólnej zbiorowej pamięci traumy związanej z nazistowskimi prześladowaniami prowadzącymi do ludobójstwa. Niemniej jednak pamięć traumatycznych wy- 
darzeń istnieje w społecznościach romskich, z tym że często przyjmuje ona formy niedyskursywne. Jest mianowicie zakumulowana w tych sferach życia, w których na ogół nie mamy do czynienia z pamiętaniem: w strukturze społecznej, relacjach między płciami, wizjach świata. Taka pamięć odgrywa istotną rolę w procesie budowania romskiej tożsamości. Aby zrozumieć tę ostatnią, wykorzystałem inspiracje płynące z teorii systemów Niklasa Luhmanna oraz antropologii symbolicznej Mary Douglas i przedstawiłem relacje między romskim systemem społecznym i kulturowym jako „podwójne kodowanie”, w którym lęki egzystencjalne związane z naruszeniem społecznej granicy grupy są przekształcane w konkretny strach (a więc taki, z którym „da się coś zrobić”) ${ }^{63}$ przed naruszeniem wewnętrznych granic kulturowych i vice versa. Proces ten jest fragmentem historii, co oznacza, po pierwsze, że przyjmuje rozmaite formy w różnym czasie, oraz, po drugie, że transgresje granic, które wydarzyły się w przeszłości, mają znaczący wpływ na teraźniejsze tożsamości.

Ten „długi cień” rzucany przez przeszłość został zilustrowany przez zjawisko retradycjonalizacji niemieckich Sinti, która dokonała się w rezultacie niemożności obrony granicy grupy przed nazistowskimi prześladowaniami. Czerpiąc z własnych badań, zasugerowałem też, że coś podobnego stało się udziałem polskich Romów Karpackich, których doświadczenie ludobójstwa odróżnia od skądinąd podobnych Romów słowackich i zbliża do skądinąd odmiennych Romów z grupy Polska Roma. Prezentowana tu argumentacja wspiera tym samym wielowymiarowe rozumienie romskich tożsamości jako historycznie uwikłanych form relacji między zasobami kulturowymi a podziałami społecznymi, manifestujących się w pamięci niedyskursywnej.

\section{Non-discursive traumatic memory \\ and collective identity: \\ Roma and the experience of annihilation}

\section{Abstract}

The article presents Roma non-discursive memory that is the presence of the past, not expressed in speech or writing, but existing in practices, relations, social structures, and cultural hierarchies. This form of memory plays a particularly important role for Roma - a network of groups which in the past found it difficult to access the means of production of collective memory. The author draws upon system theory and symbolic anthropology of Mary Douglas to show how the anxieties caused

63 Powinienem w tym momencie dodać do listy inspiracji również Clifforda Geertza, zwłaszcza jego interpretację funkcji rytuałów, a także interpretacje sposobów radzenia sobie z lękiem w historii Europy przedstawione przez Jeana Delumeau; zob. C. Geertz, The Interpretations of Culture, New York 1973; J. Delumeau, Strach w kulturze Zachodu XIV-XVIII w., przeł. A. Szymanowski, Warszawa 1986. 
by traumatic historical events, involving the violation of the external boundaries of the Roma community, are non-discursively encoded in its social structure and culture. In consequence, the author argues that the impossibility of protecting the external boundary (for example of an efficient defense against persecution) leads to a compensating control of intra-group boundaries - for example to the strengthening of the patriarchal relations between men and women. This claim is evidenced by the different status of women in the otherwise culturally similar groups of Polish Carpathian Roma and Slovak Roma which the author explains by different experiences of the World War Two which characterize these two groups and their different forms of non-discursive memory.

Keywords: non-discursive collective memory, collective identity, Roma, genealogies of memory, traumatizing event, encoding of anxiety, patriarchal gender relations

\section{Bibliografia}

Alexander J.C., Trauma. A Social Theory, Cambridge 2012.

Appadurai A., Putting hierarchy in its place, „Cultural Anthropology” 13, 1988, nr 1.

Assmann A., Transformations between history and memory, „Social Research” 75, 2008, nr 1.

Barth F., Ethnic Groups and Boundaries, Boston 1969.

Bauman Z., Mortality, Immortality and Other Life Strategies, Cambridge 1992.

Brison S.J., Trauma narratives and the remaking of the self, [w:] Acts of Memory. Cultural Recall in the Present, red. M. Bal, J. Crewe, L. Spitzer, Hanover-London 1999.

Cioran E.M., All Gall is Divided, New York 1999.

Crowe D.M., Reflections on the Roma and the Holocaust, [w:] Roma and Sinti. Under-Studied Victims of Nazism. Symposium Proceedings, Washington 2004.

Delanty G., Social Theory in a Changing World. Conceptions of Modernity, Cambridge 1999.

Delumeau J., Strach w kulturze Zachodu XIV-XVIII w., przeł. A. Szymanowski, Warszawa 1986.

Douglas M., Purity and Danger. An Analysis of the Concepts of Pollution and Taboo, London 1966. Fabian J., Time and the Other. How Anthropology Makes Its Object, New York 1983.

Fein H., Accounting for Genocide: National Responses and Jewish Victimization during the Holocaust, Chicago 1979.

Fitzpatrick M.P., Purge the Empire: Mass Expulsions in Germany 1871-1914, Oxford 2015.

Friedman J., Cultural Identity and Global Process, London 1994.

Geertz C., The Interpretations of Culture, New York 1973.

Goody J., Mit, rytuat i oralność, przeł. O. Kaczmarek, Warszawa 2012.

Hoffman E., After Such Knowledge. A Meditation on the Aftermath of the Holocaust, London 2004.

Huyssen A., Present pasts: Media, politics, amnesia, „Public Culture” 12, 2000, nr 1.

Ioanid R., The Holocaust in Romania. The Destruction of Jews and Gypsies Under the Antonescu Regime 1940-1944, Chicago 2000.

Jasper J.M., McGarry A., Introduction. The identity dilemma, social movements, and contested identity, [w:] The Identity Dilemma. Social Movements and Collective Identity, red. A. McGarry, J.M. Jasper, Philadelphia 2015.

Kania I., Cioran, albo o anachronizmie mądrości, [w:] E. Cioran, Zły demiurg, przeł. I. Kania, Kraków 1995.

Kantorowicz E.H., The King's Two Bodies: A Study in Mediaeval Political Theology, Princeton 1957.

Kapralski S., Doświadczenie zagłady i początki samoorganizacji niemieckich Sinti, „Studia Romologica" 2015, nr 8.

Prace Kulturoznawcze 24, nr 2, 2020

(C) for this edition by CNS 
Kapralski S., The Holocaust: Commemorated but not remembered? Post-colonial and post-traumatic perspectives on the reception of the Holocaust memory discourse in Poland, „Journal of Historical Sociology" 31, 2018, nr 1.

Kapralski S., Milczenie - pamięć - tożsamość. Fantazmat „Cygana” i ambiwalencja nowoczesności, „Ethos” 29, 2016, nr 1 (113).

Kapralski S., Naród z popiołów. Pamięć zagłady a tożsamość Romów, Warszawa 2012.

Kapralski S., Sytuacja kobiet romskich w Polsce i na Stowacji z punktu widzenia romskich aktywistek. Wstępne rezultaty badania pilotażowego, „Studia Romologica” 2014, $\mathrm{nr} 7$.

Kenrick D., The genocide of the Gypsies: What we now know and what we still don't know, „The Holocaust in History and Memory" 3, 2010.

Kenrick D., Puxon G., The Destiny of Europe's Gypsies, London 1972.

Kenrick D., Puxon G., Gypsies under the Swastika, Hatfield 1995.

Leder A., Prześniona rewolucja. Ćwiczenie z logiki historycznej, Warszawa 2014.

Levy D., Sznaider N., The Holocaust and Memory in the Global Age, Philadelphia 2006.

Levy D., Sznaider N., Memory unbound: The Holocaust and the formation of cosmopolitan memory, „European Journal of Social Theory” 5, 2002, nr 1.

Lutz B.D., Lutz J.M., Gypsies as victims of the Holocaust, „Holocaust and Genocide Studies” 9, 1995, nr 3 .

Marody M., Jednostka po nowoczesności. Perspektywa socjologiczna, Warszawa 2014.

Martins-Heuß K., Reflections on the collective identity of German Roma and Sinti (Gypsies) after national socialism, „Holocaust and Genocide Studies” 4, 1989, $\mathrm{nr} 2$.

Mälksoo M., ,,Memory must be defended”: Beyond the politics of mnemonical security, „Security Dialogue" 46, 2015, nr 3.

Mirga A., Roma genocide: Historic and symbolic meanings for collective memory and identity, [w:] Education for Remembrance of the Roma Genocide. Scholarship, Commemoration and the Role of Youth, red. A. Mirga-Kruszelnicka, E. Acuña, P. Trojański, Kraków 2015.

Mróz L., Niepamięć nie jest zapominaniem. Cyganie-Romowie a Holokaust, „Przegląd Socjologiczny" 49, 2000, nr 2.

Nicolae V., Slavik H., Being “Gypsy”: The Worst Social Stigma in Romania, European Roma Rights Centre 2003, www.errc.org/article/being-a-gypsy-the-worst-social-stigma-in-romania/1385 (dostęp: 8.02.2016).

Podolinská T., Hrustič T., Religion as Path to Change? The Possibilities of Social Inclusion of the Roma in Slovakia, Bratislava 2011.

Scott J., Conceptualising the Social World. Principles of Sociological Analysis, Cambridge 2011.

Sendyka R., Niepamięć albo o sytuowaniu wiedzy o formach pamiętania, „Teksty Drugie” 2015, nr 6.

Steinlauf M.C., Bondage to the Dead. Poland and the Memory of the Holocaust, Syracuse 1997.

Stewart M., How does genocide happen?, [w:] Questions of Anthropology, red. R. Astuti, J. Parry, C. Stafford, Oxford 2007.

Stewart M., The Time of the Gypsies, Colorado 1997.

Stier O.B., Committed to Memory. Cultural Mediations of the Holocaust, Amherst-Boston 2003.

Tcherenkov L., Laederich S., The Rroma, t. 1. History, Language, and Groups, Basel 2004.

Tcherenkov L., Laederich S., The Rroma, t. 2. Traditions and Texts, Basel 2004.

Trouillot M.R., Silencing the Past. Power and the Production of History, Boston 1995.

Trumpener K., The time of the Gypsies. A "people without history" in the narratives of the west, „Critical Inquiry” 1992, nr 18.

Van Alphen E., Symptoms of discursivity: Experience, memory, and trauma, [w:] Acts of Memory. Cultural Recall in the Present, red. M. Bal, J. Crewe, L. Spitzer, Hanover-London 1999.

Von dem Knesebeck J., The Roma Struggle for Compensation in Post-War Germany, Hatfield 2011.

Prace Kulturoznawcze 24, nr 2, 2020

(C) for this edition by CNS 
Wippermann W., ,, Wie die Zigeuner”. Antisemitismus und Antiziganismus im Vergleich, Berlin 1997. Wolf E.R., Europe and the People without History, Berkley-Los Angeles 1982.

Yerushalmi Y.H., Zakhor: Jewish History and Jewish Memory, Seattle 1996.

Zerubavel E., Hidden in Plain Sight: The Social Structure of Irrelevance, Oxford 2015.

Zimmermann M., Rassenutopie und Genozid. Die nationalsozialistische Lösung der Zigeunerfrage, Hamburg 1996.

Zimmermann M., The Wehrmacht and the national socialist persecution of the Gypsies, „Romani Studies" 11, 2001, nr 2.

$$
* * *
$$

Sławomir Kapralski — doktor habilitowany, profesor UP; pracuje na Uniwersytecie Pedagogicznym w Krakowie, a także regularnie wykłada w Szkole Nauk Społecznych IFiS PAN w Warszawie. Jest absolwentem Uniwersytetu Jagiellońskiego, gdzie również obronił doktorat i rozpoczął pracę naukową. Później przez wiele lat był związany z Central European University w Pradze, Warszawie i Budapeszcie. W latach 2013-2014 przebywał jako Senior Fellow w Vienna Wiesenthal Institute for Holocaust Studies, a w latach 2016-2017 jako Senior EURIAS Fellow w Swedish Collegium for Advanced Study w Uppsali. Zajmuje się nacjonalizmami i stosunkami etnicznymi, tożsamością i pamięcią zbiorową, antysemityzmem i Holokaustem, a także problemami romskich społeczności Europy.

slawomir.kapralski@up.krakow.pl 